\title{
Pemodelan Curah Hujan Bulanan Di Kabupaten Sintang Menggunakan Metode Monte Carlo dengan Algoritma Metropolis
}

\author{
Atang Rahma Agusta ${ }^{* *}$, Yudha Arman ${ }^{1)}$, Andi Ihwan ${ }^{1)}$
}

\author{
1) Jurusan Fisika Fakultas MIPA Universitas Tanjungpura Pontianak \\ *Email : atang agus@yahoo.co.id
}

\begin{abstract}
Abstrak
Telah dibangun model inversi untuk mengestimasi curah hujan bulanan dengan rentang waktu 12 tahun, yaitu dimulai dari tahun 1999 hingga 2010 di Kabupaten Sintang menggunakan metode Monte Carlo Algoritma Metropolis dengan hampiran pemodelan kedepan menggunakan deret Fourier. Dari hasil simulasi diperoleh bahwa kemiripan pola terhadap deret waktu tersebut dimiliki oleh deret Fourier yang berorde besar, yaitu pada orde 17. Hasil estimasi tersebut kemudian divalidasi dengan data tahun 2011 hingga 2012 menghasilkan koefisien korelasi sebesar 0,68. Prediksi untuk curah hujan pada tahun 2013 menunjukkan pola curah hujan di Kabupaten Sintang adalah pola hujan monsun dengan puncak curah hujan terjadi pada bulan Januari.
\end{abstract}

Kata Kunci : Metode Monte Carlo, Algoritma Metropolis, Deret Fourier

\section{LatarBelakang}

Pada umumnya, model yang digunakan untuk menghampiri data-data meteorologi bersifat non-linier. Sebab data-data meteorologi merupakan data deret waktu yang sangat fluktuatif. Selain itu, pengaruh faktor geografis serta karena efek yang disebabkan dari rotasi bumi akan semakin menambah kompleksitas data meteorologi. Kondisi tersebut terjadi pada data meteorologi provinsi Kalimantan Barat yang dilalui oleh garis Khastulistiwa. Sebagai salah satu Kabupaten di Provinsi Kalimantan Barat yang memiliki letak geografis $1^{\circ} 05^{\prime} \mathrm{LU}$ 1021'LS dan 110 ${ }^{\circ} 0^{\prime}$ - 113020' BT, Kabupaten Sintang memiliki data meteorologi yang cukup kompleks.

Korelasi yang cukup baik ditunjukkan pada pemodelan inversi kuadrat terkecil non-linier untuk data curah hujan di wilayah Provinsi Kalimantan Barat dengan mengasumsikan data meteorologi sesuai dengan sifat-sifat deret Fourier (Zulfisari, 2012). Selain itu, asumsi yang sama juga digunakan pada pemodelan menggunakan metode Simulated Annealing pada data curah hujan di lingkup wilayah geografis yang sama (Arman, Y., 2012) yang menghasilkan nilai korelasi yang cukup baik. Hal ini menunjukkan bahwa data meterologi pada beberapa tempat di wilayah Kalimantan Barat memiliki kemiripan pola dengan deret Fourier.

Kendala yang dihadapi pada pemodelan data yang menggunakan model inversi non linier dengan pendekatan linier adalah terjebaknya solusi pada wilayah minimum lokal fungsi obyektif sehingga menyimpang dari kondisi fisis. Kondisi ini umumnya terjadi pada pemodelan yang berbasis pada line-search, dimana parameter model yang dievaluasi terbatas pada ruang lingkup model tersebut ( Asriadi, A., 2007).

Untuk mengatasi kendala tersebut ruang model diperluas dengan menggunakan metode berbasis pencarian acak (Basuki, A., 2004). Penggunaan metode pencarian acak untuk tipe data deret waktu yang fluktuatif telah dilakukan sebelumnya oleh penelitian simulasi Monte Carlo dalam menentukan nilai opsi saham (Muniroh, W. S., 2008) untuk data saham. Berdasarkan pernyataan tersebut di atas, pada penelitian ini dibuat model inversi data curah hujan Kabupaten Sintang menggunakan Metode Monte Carlo Algoritma Metropolis dengan hampiran pemodelan kedepan menggunakan deret Fourier.

\section{Metodologi}

Pada metode Monte Carlo dengan algoritma Metropolis proses pemodelan dimulai dengan mensubsititusikan parameter model awal. Parameter model awal akan diperbarui untuk menghasilkan parameter model baru yang termodifikasi menggunakan persamaan:

$$
m_{1 i}=m_{0 i}+0,01 m_{0 i} r_{a}
$$

dengan $\mathrm{m}_{0}$ adalah parameter model awal, $\mathrm{m}_{1}$ adalah parameter model baru, i menyatakan jumlah parameter model yang digunakan dan $r_{a}$ adalah bilangan acak berdistribusi normal pada rentang 0 (nol) hingga 1 (satu).

Proses yang dikerjakan berikutnya adalah mensubstitusikan parameter model yang dihasilkan ke dalam Forward modelling. Proses ini memetakan parameter model menjadi data kalkulasi. Fungsi model yang digunakan adalah deret Fourier dengan bentuk umum sesuai dengan persamaan berikut (Spiegel, M.R., 1984): 


$$
F(x)=a_{0}+\sum_{n=1}^{\infty} a_{n} \cos (n \omega x)+b_{n} \sin (n \omega x)
$$

dengan $\mathrm{n}$ menyatakan orde dari persamaan tersebut, $x$ adalah peubah bebas dan $\omega$ adalah frekuensi sudut. Untuk menyesuaikan dengan data observasi, pada pemodelan ini diambil nilai mutlak dari deret Fourier yang digunakan.

Sebuah model akan diterima sebagai solusi berdasarkan nilai Root Mean Square Error (RMSE) atau akar kuadrat rata-rata selisih antara data observasi dengan hasil forward modelling model tersebut. Selisih RMSE model termodifikasi dengan RMSE model awal didefinisikan sebagai $\Delta \mathrm{E}$. Apabila $\Delta \mathrm{E}$ bernilai negatif maka model baru diterima sebagai solusi. Jika kriteria ini tidak terpenuhi, model masih memiliki peluang untuk menjadi solusi apabila nilai bobot dari model baru tersebut lebih kecil dari nilai sebuah bilangan acak yang berdistribusi normal. Bobot dari model tersebut sesuai dengan persamaan (Gould, dkk, 2007):

$$
w=e^{-\beta \Delta E}
$$

dengan w adalah bobot solusi dan

$$
\beta=\frac{1}{k_{b} T}
$$

adalah sebuah konstanta dengan $k_{B}$ adalah konstanta Boltzmann dan T adalah suhu. Proses tersebut akan terus diulang hingga kriteria solusi yang ditetapkan tercapai atau jumlah maksimum iterasi terpenuhi. Diagram alir pemodelan disajikan pada Gambar 1 .

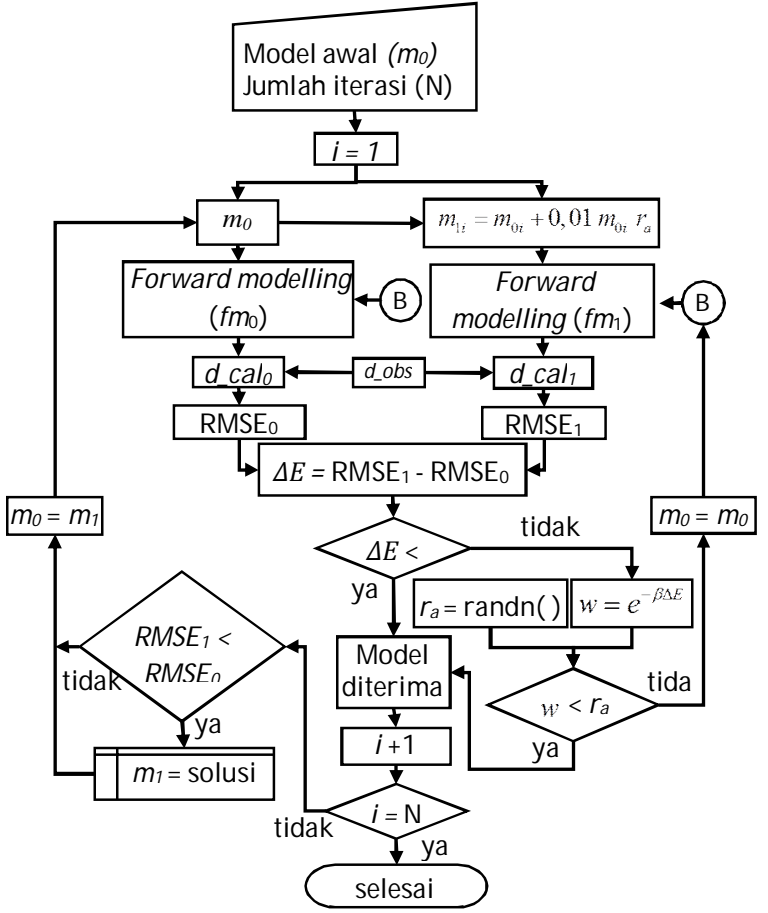

Gambar 1. Diagram alir pemodelan dengan algoritma Metropolis

\section{Hasil dan Pembahasan}

Prediksi curah hujan pada tahun 2013 di Kabupaten Sintang dapat diperoleh dengan memanfaatkan data curah hujan sebelumnya. Data observasi yang digunakan dalam pemodelan adalah data curah hujan memiliki rentang waktu 12 tahun, yaitu dimulai dari tahun 1999 hingga tahun 2010. Model dihasilkan dengan mensubsitusikan parameter model awal kedalam Forward modelling dengan deret Fourier sebagai fungsi modelnya. Setelah memperoleh model baru dengan korelasi estimasi paling tinggi, parameter model baru digunakan dalam validasi model. Validasi model menggunakan data tahun 2011 hingga 2012. Jika pada proses validasi menghasilkan koefisien korelasi lebih besar dari 0,6 maka parameter model yang dihasilkan dianggap dapat mempresentasikan kondisi sebenarnya.

Simulasi dilakukan menggunakan berbagai orde deret Fourier. Hasil simulasi disajikan pada Tabel 1. Terlihat pada orde 17 hasil proses pemodelan menunjukan nilai terbaik, yaitu nilai korelasi 0,56 dan RMSE 120,90. Nilai tersebut diperoleh pada iterasi ke 7500 seperti yang disajikan pada Gambar 2.

\begin{tabular}{|c|c|c|c|c|c|}
\hline 1 & 0,14 & 139,90 & 11 & 0,48 & 129,03 \\
\hline 2 & 0,15 & 140,12 & 12 & 0,51 & 126,06 \\
\hline 3 & 0,15 & 139,49 & 13 & 0,51 & 126,86 \\
\hline 4 & 0,15 & 139,57 & 14 & 0,48 & 128,14 \\
\hline 5 & 0,42 & 128,82 & 15 & 0,48 & 129,36 \\
\hline 6 & 0,44 & 128,24 & 16 & 0,54 & 122,27 \\
\hline 7 & 0,49 & 128,78 & 17 & 0,56 & 120,90 \\
\hline 8 & 0,48 & 127,83 & 18 & 0,55 & 121,07 \\
\hline 9 & 0,49 & 128,21 & 19 & 0,55 & 123,08 \\
\hline 10 & 0,46 & 126,45 & 20 & 0,55 & 120,99 \\
\hline
\end{tabular}

Tabel 1. Hasil korelasi estimasi dan RMSE

\section{Orde Korelasi RMSE}

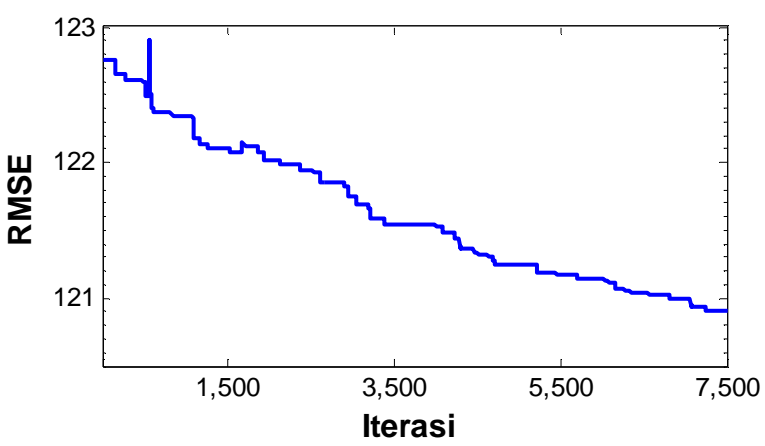

Gambar 2. Grafik RMSE orde 17 dengan nilai RMSE 120,90 


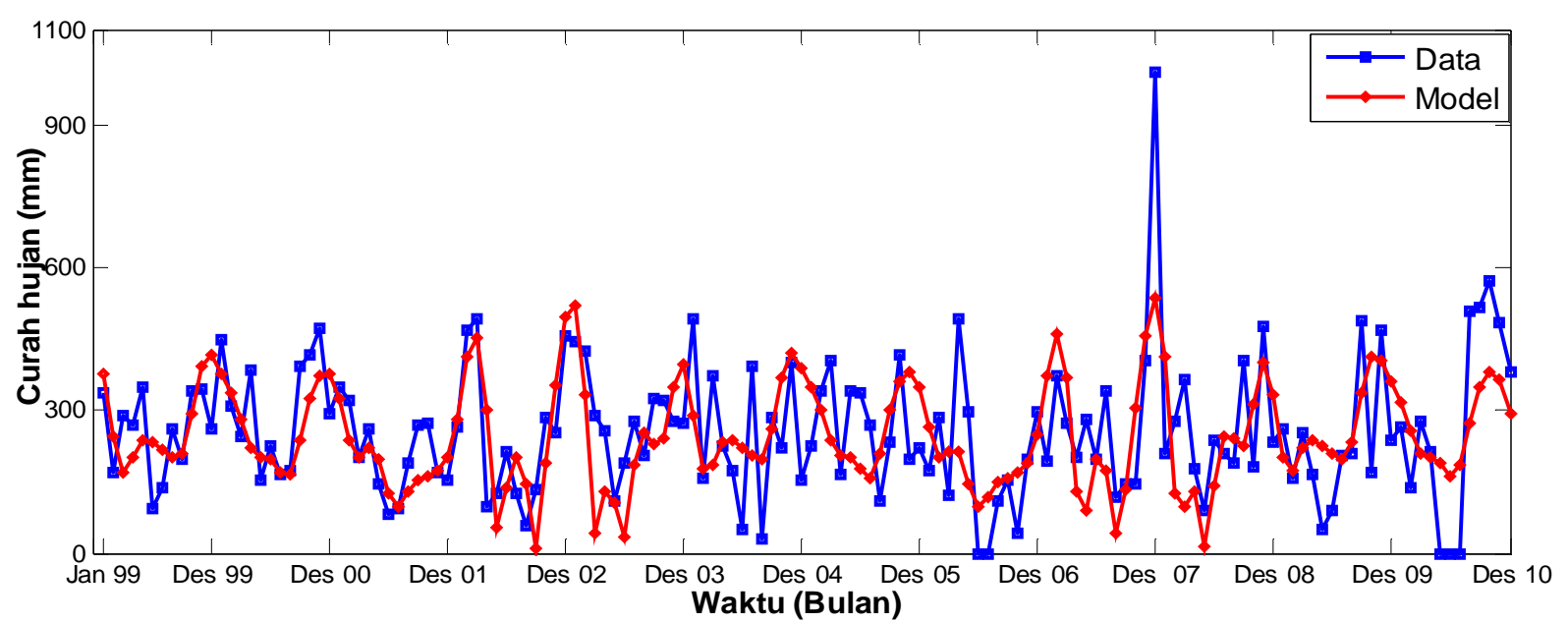

Gambar 3. Grafik model dan garfik data observasi terhadap caurah hujan

Hasil validasi pada data tahun 2011 hingga 2012 menghasilkan koefisien korelasi sebesar 0,68 dengan nilai RMSE 85,86. Hasil yang diperoleh menunjukkan bahwa model yang dihasilkan memiliki hubungan yang kuat dengan data. Bentuk grafik hasil validasinya seperti yang disajikan oleh Gambar 4 berikut:

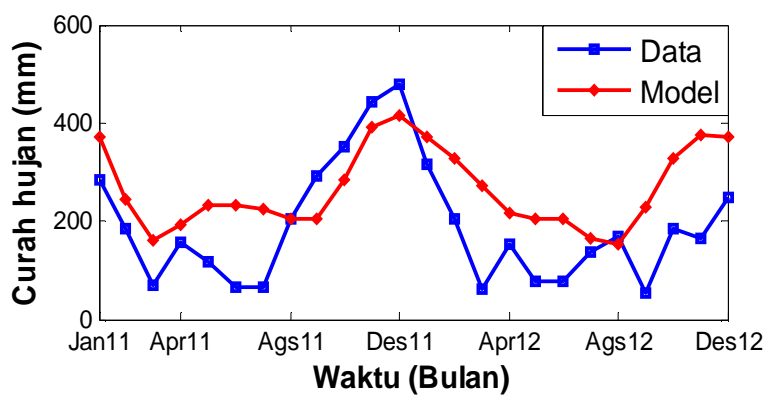

Gambar 4. Hasil validasi model dengan koefisien korelasi 0,68

Model tersebut kemudian digunakan untuk melakukan prediksi curah hujan bulanan pada tahun 2013. Hasil prediksi disajikan pada Gambar 5. Terlihat bahwa pada curah hujan yang terbentuk merupakan pola hujan monsun dengan puncak nilai curah hujannya terjadi pada bulan Januari.

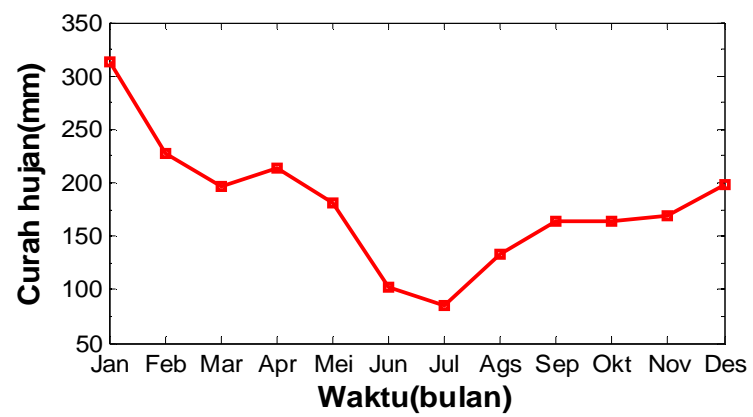

Gambar 5. Grafik prediksi curah hujan bulanan pada tahun 2013

\section{Kesimpulan}

Pada pemodelan curah hujan di Kabupaten Sintang, deret Fourier yang memiliki orde 17 menghasilkan koefisien korelasi terbaik, yaitu sebesar 0,68 dengan simpangan nilai RMSE 85,86 untuk data validasi tahun 2011 hingga 2012. Model curah hujan yang dihasilkan mengestimasi nilai titik maksimum curah hujan tahun 2013 terjadi pada bulan Januari, yaitu $312,76 \mathrm{~mm}$ dan nilai titik minimumnya terjadi pada bulan Juli, yaitu $84,66 \mathrm{~mm}$.

\section{DaftarPustaka}

Arman, Y., 2012, Pemodelan Curah Hujan di Kota Ketapang Menggunakan Metode Simulated Annealing, JAF volume 8.

Asriadi, A., 2007, Simulasi Stokastik Menggunakan Algoritma Metropolis Hastings, JMAP Vol. 6 No 2

Basuki, A., 2004, Modeling dan Simulasi, IPTAQ Mulia Media, Jakarta Timur.

Gould, H., Tobochnik, J., Christian,w ., Davidson College., 2007, An Introduction To Computer Simulation Methods Applications to Physical Systems, Third Edition, Davidson College, Wesley, San Francisko.

Muniroh, W. S., 2008, Simulasi Monte Carlo Dalam Menentukan Nilai Opsi Saham, UIN Malang Press, Malang (Skripsi S1).

Spiegel, M. R., 1984, Transformasi Laplace, Alih Bahasa, Silaban, Wospakrik, Erlangga, Jakarta.

Zulfisari, 2012, Model Curah Hujan Bulanan Dikalimantan Barat Berdasarkan Metode Gauss Newton, UNTAN press, Pontianak (Skripsi S1). 